\title{
INFLUÊNCIAS NA VALORAÇÃO DO FALIDO NO HISTÓRICO DA PROTEÇÃO JURÍDICA DA RECUPERAÇÃO DE EMPRESAS
}

\section{Norton Maldonado Dias}

Mestre em Direito (2016) pelo Centro Universitário Eurípedes de Marília). Membro do grupo de pesquisa do Centro Universitário Eurípides de Soares da Rocha - Univem, indexado ao diretório do CNPq: Gramática dos Direitos Fundamentais. Graduação (2009). Especialização em Direito Internacional e Econômico - Pós-Graduação - 2012 (UEL - Universidade Estadual de Londrina - Paraná). Advogado. Professor das disciplinas de Direito Constitucional e Teoria Geral do Direito Civil da Faculdade de Direito de Sinopi/ Mato Grosso (Grupo Fasip). Exerce a advocacia com escritório no Centro da cidade de Marília - SP, desde 2010. maldonadodias@hotmail.com.br

\section{Resumo}

0 trabalho procurou tratar da valoração histórica e cultural acerca do falido como um precedente necessário para a admissão de prerrogativas que considerassem direitos de recuperação ao empresário em crise. As oscilações históricas do instituto da recuperação no ordenamento jurídico brasileiro, enfatizando a abolição e restauração dos modelos extrajudiciais no reestabelecimento do empresário, atentando as problemáticas da concordata, correspondem, justamente, a uma análise valorativa de evolução axiológica da figura do falido que releva a noção atual da atividade empresária contextualizada em meio à estabilização da função social e outros valores, dentre os quais a preservação da empresa.

\section{Palavras-chave}

Recuperação de empresas. Empresário falido.

\section{INFLUENCES IN THE VALUATION OF THE BANKRUPT LEGAL PROTECTION OF THE HISTORIC RECOVERY OF COMPANIES}

\section{Abstract}

The study sought to address the historical and cultural value about brankrupt as necessary precedente for admission of powers which consider recovery rights to the entrepreneur in crisis. The historical oscillations of recovery institute in the Brazilian legal system, emphasizing the abolition and restoration of extrajudicial models in the reestablishment of the entrepreneur, considering the problems of bankruptcy, correspond precisely one evaluative 
analysis of axiological evolution of bankupt figure wich comes under the current notion of contextual business activity amid stabilization of the social function and other values, among which, company's preservation.

\section{Keywords}

Company Recovery. Businessman Bankupt.

\section{Sumário}

1. Introdução. 2. Da influência da forma de valorar o falido no surgimento da recuperação de empresas. 3. Do histórico do instituto da recuperação no ordenamento pátrio e os acordos extrajudiciais abolidos do ordenamento. 4. Da nova lei de falências (lei n. 11.101/2005) e da revogação do antigo regime de concordatas. 5. Das razões da legalização da forma extrajudicial de recuperação. 6. Considerações finais. 7. Referências. 


\section{INTRODUÇÃO}

O trabalho concentra no contexto histórico da recuperação extrajudicial, de modo que seus aspectos históricos possuem significativas relevâncias a serem destacadas, dentre as quais a visão negativa e o juízo de valor que se fazia do falido, demonstrando uma ideia de punição que sancionava ocorrência de uma falência, inclusive repudiando a ideia de leis que estruturassem prerrogativas de reestruturação do comerciante em crise como forma de punir mesmo o falido.

Neste propósito, enfatiza-se prioritariamente o histórico do modelo extrajudicial no ordenamento jurídico brasileiro, relatando oscilaçôes na sua previsão jurídica que ora era regulamentada e ora deixava de ser disciplinada sob o argumento de prevenir a prerrogativa de recuperação do empresário das fraudes que poderiam ser facilitadas com uma modalidade menos formal e extrajudicial.

A importância de trabalhar os aspectos técnicos está no fato de que serão as abordagens técnicas que determinarão os detalhes, em comparação com o modelo mais formal de recuperação, que devem estar comprometendo o instituto, expondo a ocorrência de conluios e fraudes por parte dos envolvidos na relação.

Não se pode deixar de abordar que as definiçôes mais técnicas de fraude à luz da vigente Lei de Falência (Lei n. 11.101/2005) foram bastante significativas, pois a ideia de se afastar a prerrogativa extrajudicial de recuperaçáo do empresário sob o pretexto de prevenir de possíveis fraudes deveria ser contrapesada com tratamentos da própria legislação falimentar que previu parâmetros para a noção de fraudes, sem definir, de forma expressa, tais condutas maliciosas no prejuízo de terceiros.

Desse modo, a proposta buscou relatar a valoraçáo que teve de superada acerca do falido na admissão de uma modalidade menos formal e extrajudicial de recuperação, sem que as fraudes deixassem de ser uma preocupação da nova noção de empresário que deveria ser vislumbrado à luz de inovadores princípios, dentre os quais, função social e preservação da empresa. 


\section{DA INFLUÊNCIA DA FORMA DE VALORAR O FALIDO NO SURGIMENTO DA RECUPERAÇÃO DE EMPRESAS}

É excepcional relevância tratar a falência antes de passar diretamente ao sistema de reestruturação da atividade econômica e antes de tratar das possíveis fraudes decorrentes do seu processo.

Ocorre que a oportunidade ou favor concedido ao falido na prerrogativa de reestruturar sua atividade econômica possui ligação histórica de uma mudança de pensamento na valoração que se atribuía àquele que faliu ou teve sua atividade econômica afetada pela crise.

A valoração do falido, além de estar diretamente ligada à oportunidade de previsão de uma forma institucional que permitisse a recuperação do empresário em crise, ainda se liga diretamente à figura da fraude na própria origem etimológica "falência".

Lacerda (1999, p. 242) destaca que a expressão carrega no respectivo nome a ideia originária daquele que perdia o seu negócio por conta da impossibilidade de pagar afirmando: "Fallitus, ergo fraudator, de Baldo, concretizava a rigorosa teoria do direito italiano".

Verifica-se o juízo de valor negativo da época do surgimento da falência na maneira como se punia o falido, a ponto de equiparar o falido a um criminoso, ponto de vista este que impedia posição qualquer na concessão de prerrogativa de reestruturação da atividade econômica, de tal sorte que a modalidade institucional de recuperação do comerciante somente conseguiu sua positivaçáo na lei depois de árduo caminho e difícil conquista histórica.

O surgimento da falência foi marcado por uma rigorosa teoria do Direito Italiano que não distinguia os devedores fraudulentos dos de boa-fé, estendendo-se a todos duras e vexatórias repressóes decorrentes da ideia de falido, marcada pelo preconceito e suspeita de infâmia e fraudes no tocante ao falido, incluindo aquele que foi vítima das instabilidades de mercado. Por isso, a falência foi disciplinada pelo Direito Penal, como bem destaca Requião (1995a, p. 9): "A repressão penal é traço característico do instituto falimentar nessa fase". 
Ainda assevera Requião (1995a, p. 10), ressaltando que não foi fácil a falência desprender-se do Direito Penal, fruto da arcaica visão valorativa: "Não foi fácil o instituto desprender-se de seus vínculos penalistas. Caracterizava-se a incipiente teoria falimentar, na Idade Média, pelo axioma decoctor ergo fraudator".

Foi na antiga falência, de caráter repressivo, que predominou o pensamento de punir o devedor que iludira a confiança dos outros de maneira criminosa. Tal pensamento pode ser verificado no costume, na França e Itália, conforme Lacerda (1999, p. 242) salienta: "expor o falido ao desprezo público, obrigando-o ao uso permanente do barrete verde ou, então, a percorrer, em camisa, as ruas da cidade".

Requião (apud Almeida, 1997, p. 4) destaca que a Idade Média é um exemplo de fase de enquadramento de atuação de credores à disciplina Judiciária, quando o concurso de credores foi rigidamente disciplinado e a falência vista como conduta delituosa:

Na Idade Média, contudo, a tutela estatal assume especial relevo, condicionando a atuação dos credores à disciplina judiciária [...]. Nessa fase, a falência é vista como um delito, cercando-se o falido de infâmia e impondo-se-lhe penas que vão da prisão à mutilação - falliti sunt fraudatores (Os falidos são fraudadores, enganadores e velhacos). Daí a expressão falência, do verbo latino fallere, que significa enganar, falsear.

As expressôes "bancarrota" e "quebra" foram terminologias comuns para o Direito. Embora bancarrota não tenha subsistido entre nós, é comum nas doutrinas e no estudo do Direito Comercial. Assim destaca Requião (1995b, p. 4):

A expressão bancarrota não subsistiu entre nós. No Código Criminal de 1830, todavia, teve sua voga, para designar a falência fraudulenta. Nisso ficou seu uso, não tendo prosperado. Mas no direito estrangeiro, como o francês e italiano, a expressão bancarrota permaneceu, designando a falência culposa ou fraudulenta. No idioma inglês, no direito norte-americano ou britânico, bankrupticy, é expressáo usada para todas as espécies de falência. 
No que diz respeito à expressão das "quebras", as Ordenaçóes do Reino, desde 1521, e no nosso famoso Código Comercial de 1850, que tratou da redação: “Das Quebras” e que, portanto, vale tratar de tal terminologia, destaca Requião (1995a, p. 3) que:

No idioma português, sobretudo na Linguagem das Ordenaçóes do Reino, desde as Ordenaçóes Manuelinas (1521), usava-se a palavra quebra - (E porém quando alguém quebrar queremos que dentro de um, mas inteiro do dia que quebrar aproveite diligência alguma, Liv. III Tít. 74, n. 3). Convém notar, porém que a expressão falência já era usada no Alvará de 1756, baixado pelo Marquês de Pombal, quando alterou parte das Ordenaçóes Filipinas. Nesse Alvará já se usavam indistintamente as duas expressóes - quebra e falência - embora houvesse prevalência da primeira.

Ao tratar da expressão da "quebra", não se pode esquecer do Código Comercial de 1850, que teve, em um de seus títulos, "Das Quebras”, para enunciar a matéria. Requião (1995b, p. 3) expóe:

Explica-se assim ter o nosso Código Comercial de 1850, no purismo vernacular de sua redação, preferido o título “Das Quebras”, na sua Parte Terceira, para comunicar a matéria, embora o texto do art. 798 registrasse a sinonímia das duas expressóes jurídicas: "A quebra ou falência pode ser casual, com culpa ou fraudulenta”.

Na própria expressão usada para designar a falência, portanto, está o aspecto delituoso, originariamente valorado, que justificou o Direito Repressor usado na época para punir o falido, mais especificamente usado nas cidades italianas, onde foi de grande incidência nas feiras, na atividade mercantil, quando houve predomínio do primitivo direito comercial. Sobre o assunto, Requiāo (1995a, p. 9) acrescenta:

Nas cidades italianas, o primitivo direito comercial predomina, integrando-se, muitas vezes, no direito comunal. É nesse ambiente, de viva atividade mercantil, que se delineia, a partir do concurso creditorum, do direito romano, o incipente direito falimentar, com sentido mais severo. Ao falido se reservava toda sorte de 
vexames, que o tornava, com a pena de infâmia, um réprobo social. Nenhuma distinção existia entre a insolvência do devedor comerciante e a do náo-comerciante. Todos, indistintamente, se sujeitavam às regras de direito falimentar.

Não somente na Itália e França, porém, houve esse pensamento repressivo ao falido, por conta da arcaica visão de falência de forma delituosa. Requiáo (1995b, p. 9) menciona também a Inglaterra: “Tanto na Itália, como na França ou na Inglaterra, as normas falimentares visavam a reprimir os abusos cometidos pelos devedores desonestos, sob os mesmos títulos de que puniam os delinqüentes comuns".

$\mathrm{Na}$ Inglaterra pode se verificar, na lei inglesa de 1676, que os comissários da falência poderiam se apoderar da pessoa do devedor, dispor de seus bens, usar com ele o famoso pelourinho, ablação de orelhas, dentre outras sançóes desproporcionais.

Requiāo (1995b, p. 9) comenta que:

A prisão do devedor insolvável, com aplicação de penas vexatórias e degradantes, era uma constante no direito da época. Pode-se imaginar a severidade dessa repressão, quando se lê numa lei inglesa de 1676 que os comissários da falência tinham poderes muito extensos, podendo se apoderar da pessoa do devedor, dispuser de seus bens, submetê-los ao pelourinho e condená-lo à ablaçáo das orelhas, se tivesse fraudulentamente subtraído bens de um valor superior a vinte libras (Del Marmol, La Faillite em droit anglo-saxon, p. 15).

O pensamento radical que equiparava o devedor ao criminoso teve significativo gravame. Aquele que, principalmente, agira honestamente, temendo cair em falência, em decorrência de incidentes imprevistos, procurava em operaçóes arriscadas meios de evitar a declaração, resultado no qual, segundo Lacerda (1999, p. 242): "não conseguindo desvencilhar do desastre, maiores ainda se tornavam os prejuízos para os credores".

No tocante à mudança de se pensar o falido, destaca-se o Código Francês de 1807, quando houve predomínio da atuação de políticas de restrições e rigores ao falido que foram, com o tempo, gradativamente sendo relativizados pelas disciplinas ulteriores. Almeida (1997, p. 5) faz seu comentário: 
O Código Comercial francês, de 1807, na elaboração do qual Napoleão Bonaparte teve preponderante atuaçáo, conquanto impondo severas restriçôes ao falido, constitui-se em inegável evolução do instituto, restrito, na legislação francesa, ao devedor comerciante.

Um grande avanço do ponto de vista histórico e valorativo para o surgimento dos sistemas de reestruturação da atividade econômica foi a distinção entre devedores honestos e desonestos, uma vez que somente no reconhecimento destes primeiros foi possível a tentativa de manter a atividade por meio de benefícios de moratória, ainda que com forma precária de aperfeiçoamento conhecido como concordata, como bem-destaca Almeida (1997, p. 5):

Faz-se, então, nítida distinção entre devedores honestos e desonestos, facultando-se a estes últimos os favores da moratória, com aperfeiçoamento da concordata, cujo embriáo encontrou no pactum est minus solvatur e no quinquenales.

A conscientização e a mudança na forma de se pensar o devedor desventurado fez com que se cogitasse a seguinte solução, como destaca Lacerda (1999, p. 242): "meios que moderassem a severidade para com os devedores desventurados, mas que, ao mesmo tempo, não sacrificassem os direitos e interesses dos credores e de terceiros”.

Foi nesta conscientização e ruptura de corresponder o falido com o fraudador, que foi reconhecida a possibilidade das instabilidades de mercado e fenômenos econômicos imprevisíveis que marcaram o começo de uma evolutiva busca institucional que contribuiu para outras preocupaçóes, além de tão somente punir o devedor, resultando, assim, em um longo processo que, mais tarde, seria responsável pelas concessóes de prerrogativas ao falido, inclusive de reestruturação da sua atividade, tal qual a revogada Concordata, ou atual Recuperação Judicial e Extrajudicial com a nova lei.

\section{DO HISTÓRICO DO INSTITUTO DA RECUPERAÇÃO NO ORDENAMENTO PÁTRIO E OS ACORDOS EXTRAJUDICIAIS ABOLIDOS DO ORDENAMENTO}

Tratar da História do instituto no Ordenamento brasileiro é imprescindível, uma vez que tal modalidade jurídica é marcada por grande instabilidade concernente às leis brasileiras que ora revogavam, ora positivavam, a vigência institucional. 
No Brasil, a primeira concordata a ser introduzida foi a concordata suspensiva, como bem explica o professor Almeida (1997, p. 373): "concordata a ser introduzida no direito brasileiro foi a concordata suspensiva, assim denominada aquela concedida no decorrer do processo falimentar, quando restituída ao falido a livre administração dos seus bens”.

A concordata preventiva foi introduzida posteriormente, como ressalta Almeida (1997, p. 373):

Em 24 de outubro de 1890, o Decreto n. 917 introduzia, entre nós, a concordata preventiva que, como o próprio nome deixa entrever, é aquela que é requerida preventivamente, como modo de evitar a declaração da falência.

O diploma legal previu duas formas de concordata preventiva. Uma primeira firmada extrajudicialmente, entre devedor e seus respectivos credores, exigindo sua homologação pelo juiz. A segunda, ao revés, era, desde logo, levada a efeito perante o juiz. Nasce aí as espécies Judicial e Extrajudicial (Almeida, 1997, p. 373).

O próprio nome concordata já pressupôe acordo de devedores e credores. Afirma Coelho (2002, p. 363): "é desse tempo o nome concordata: os credores concordavam em conceder o favor ao devedor".

O diploma que previu as formas de concordata preventiva, uma levada perante o juiz e outra firmada extrajudicialmente entre devedor e seus respectivos credores, exigindo homologação judicial, embora mantida pouco depois, não durou muito tempo em nosso ordenamento. $\mathrm{O}$ modelo foi mantido posteriormente. Conforme Almeida (1997, p. 374):

Este sistema permaneceu sob égide do Decreto n. 859 de 16 de dezembro de 1902 [...] até 17 de novembro de 1902, a lei n. 2024 consolidava de vez a concordata, quer preventiva ou suspensiva. Fundava-se a lei que nos referimos no anteprojeto do douto comercialista Carvalho Mendonça, que punha fim à concordata preventiva extrajudicial. 
Em 1929, com o advento do Decreto 5.646, adotou idêntico princípio, porém sofreu profunda alteração com a legislação do Decreto-Lei n. 7.661/45; inclusive o professor Pacheco (2001, p. 587), ao doutrinar sobre o decreto-lei n. 7.661/45, enuncia: "A concordata é processo judicial - tem de ser pedida em juízo. Não há de cogitar dos acordos amigáveis, extrajudicial”.

Assim, afirmado ser processo judicial, questiona-se a natureza jurídica da concordata, tendo como ponto de partida o decreto-lei n. 7.661/45. Andrade (1992, p. 217) assim defende a natureza processual e admite a mudança:

Decreto-lei n. 7661/45 deu uma guinada total no entendimento anterior, quanto à natureza jurídica do instituto [...]. Antes dela, a concordata sempre dependeu do consenso dos credores, daí o entendimento de um contrato entre aqueles, ao dar prazo ao devedor para cumprir a obrigação, mediante condiçóes legais [...]. Agora, não mais, pois independe dos credores concordarem ou não. Dependerá da sentença judicial [...] Verifica-se, portanto, que a natureza jurídica é processual, face ao nosso direito positivo

O Decreto-Lei n. 917 de 1980 acolheu o instituto da concordata preventiva e, concomitantemente, regulou a moratória, a cessão de bens e a liquidação judicial que posteriormente, foram revogadas em 1902 pelo decreto n. 859 .

A Lei n. 2.024 de 1908 disciplinou tanto a concordata preventiva quando a suspensiva. O decreto-lei n. 5.746/1929 manteve os institutos até o Decreto n. $7.661 / 1945$, que marcou a ruptura tradicional, sendo a concordata colocada no ordenamento por alguns como um favor.

Lacerda (1999, p. 245) assevera que: "modificou, entretanto, o sistema tradicional; não fez mais que a concessão desse favor ficasse na dependência da aprovação da maioria dos credores. Passou, então, a concordata, a ser um favor concedido pelo juiz".

O Decreto n. 7.661/45 derivava de um anteprojeto apresentado em 1939 pelo ilustre Trajano Miranda Valverde, cuja justificativa: 
Se a concordata é um favor que a lei concede ao devedor honesto e de boa-fé, injustificável, a nosso ver, o sistema geralmente adotado de deixar ao arbítrio exclusivo da outra parte - maioria dos credores - a concessão ou não desse favor (Lacerda 1999, p. 245)

Monteiro (2003, p. 134) comenta que a fraude à Lei ("fraus legis") é a hipótese onde o ato praticado é aparentemente legal, porém:

[...] debaixo dessa aparência de legalidade, se oculta um claro intento de contornar determinada proibição legal" (Monteiro, W. de Barros; 2003; p. 134). Este referido defeito, caracteriza-se primordialmente por dois elementos básicos, um primeiro que se trata de um elemento objetivo (Eventus Damni) e outro elemento subjetivo (Consilium Fraudis), sendo este o instituto malicioso de prejudicar e aquele que consiste em todo "negócio prejudicial ao credor, por tornar o devedor insolvente, ou por ter sido praticado em um estado de insolvência.

A lei buscou, com isso, evitar os acordos extraprocessos (embrionário do instituto, hoje conhecido como recuperaçáo extrajudicial) sob fundamento e preservar o princípio da igualdade que deve haver entre credores. Nas palavras do ilustre Macedo (apud Lacerda, 1999, p. 245):

A cabala campeia, em surdina, mas ativa e eficientemente, quase sempre com prejuízo dos credores que não concordassem com os cambalachos. Os pagamentos por fora, as cessóes e outros meios de burlar a lei e quebrar a igualdade entre credores eram fatores decisivos para obtenção da maioria.

Também, na mesma obra, manifesta Souza (apud Lacerda, 1999, p. 245): “o mérito do concordatário, a proclamação de sua honestidade, que só obtém quase sempre com pagamentos clandestinos sob a forma de cessóes”.

A tentativa, porém, da lei de evitar os acordos extraprocessos (embrionário do instituto hoje conhecido como recuperação extrajudicial), sob fundamento de preservar o princípio da igualdade que deve haver entre credores no regime do Decreto-lei n. 7.661/45, é de um contexto histórico, no qual a previsibilidade e a positivação eram marcantes. As causas da forte regulaçáo e da abordagem concisa podem ser verificadas na manifestaçáo de Souto Júnior (2006): 
O regime anterior de falências e concordatas brasileiro, regulado pelo Decreto-Lei 7.661/45, apesar de ter sido um marco para a sua época, estando em plena consonância com os princípios econômicos e empresariais então em vigor, na ausência de adequações, já não era mais compatível com a dinâmica econômica atual, tampouco atendia os anseios inerentes a uma legislação falimentar moderna. Talvez seja mais do que coincidência o fato do Decreto-Lei 7.661/45 ser contemporâneo à Conferência de Bretton Woods, de julho de 1945, marco da instauração da ordem mundial capitalista no pós-guerra, que vigeu, praticamente inalterada até o início dos anos 70 . O pós-guerra, do ponto de vista econômico, pode ser caracterizado, em uma abordagem concisa, como um período de previsibilidade e de forte regulação.

\section{DA NOVA LEI DE FALÊNCIAS (LEI N. 11.101/2005) E DA REVOGAÇÃO DO ANTIGO REGIME DE CONCORDATAS}

A concordata era um instrumento jurídico indispensável à recuperação econômico-financeira dos empresários, porém foi se tornando obsoleto e fora de tempo de acordo com as novas demandas que vinham surgindo, uma vez que não mais assegurava ao devedor os recursos necessários para a manutenção de estoques e continuação da atividade empresarial, como afirma Almeida (2006, p. 301):

A concordata, malgrado, constituir-se no instrumento jurídico indispensável à recuperação econômico-financeiro dos empresários, com o correr do tempo foi-se mostrando inadequada, entre outras coisas, por não assegurar ao devedor os recursos financeiros fundamentais para a manutenção de estoques e continuação da atividade empresarial. De outro lado, sem garantia efetiva de receber seus créditos, as instituições financeiras recusavam-se, sistematicamente, a financiar a atividade negocial de concordatários, tornando impraticável o fiel cumprimento das obrigaçóes destes, o que, na prática, culminava na convolação da concordata em falência, com prejuízos insanáveis para o devedor, fornecedores e empregados. 
Chegou um tempo em que o revogado Decreto-lei n. 7.661/1945 marcou-se por enorme acanhamento no rol de escolhas em negociar a reestruturação da empresa. Segundo Almeida (2001, p. 301), "Além disso, o Decreto-lei n. 7.661/1945, malgrado o esforço jurisprudencial, mostrava-se extremamente tímido nas opçóes negociais destinadas à efetiva recuperação das empresas".

Dentre os motivos das modificações, está a extinção da chamada concordata suspensiva, consistente em razóes que muito tem relaçáo com fraudes e conluios, como destaca Almeida (2006, p. 302):

Não se olvide, igualmente, a utilização, não raras vezes, do instituto da concordata, como meio de fraudar credores.

Tais aspectos, entre outros, foram os responsáveis pela alteração da legislaçáo falimentar, com adoção da denominada recuperaçáo judicial, que veio substituir a antiga concordata preventiva, sendo de todo extinta a concordata suspensiva.

Observa-se que a palavra concordata nada tem a ver com a essência institucional, diferentemente da palavra falência, que se vinculava com a natureza delituosa ao tempo em que originariamente surgiu. Além disso, ressalta-se que a concordata preventiva foi substituída pela Recuperação de Empresas com o advento da Lei n. 11.101/2005. Destaca ainda Almeida (2006, p. 301):

Uma das inovaçôes trazidas, como observa, é a alteração do nome dado ao instituto da concordata, com a adoção da denominada recuperação judicial, que veio substituir a antiga concordata preventiva, sendo de todo extinta a concordata suspensiva.

De acordo com Almeida (2006, p. 8), a "falência" há muito tempo deixou de, só por si, configurar delito, hoje se verifica:

Com efeito, a própria falência e, igualmente, a concordata, são expressóes que já náo se coadunam com a exata natureza jurídica dos institutos. 
De há muito tempo a falência deixou de, só por si, configurar um delito. É, antes de qualquer conotaçáo criminosa, uma conseqüência dos riscos dos negócios, podendo, em época de crise econômica, juros extorsivos e restriçáo da demanda, alcançar, inclusive, empresários dos mais escrupulosos. É, portanto, um percalço da atividade econômica.

A palavra concordata não tem vinculação com a essência do instituto e a nova adoção, ou seja, a expressão "recuperação" tem sua influência no sistema francês, como destaca Pacheco (2001, p. 8):

Verifica-se, pois, que a subemenda optou pela $1^{\text {a }}$ denominação dos institutos do sistema francês - recuperação judicial e liquidação judicial -, sem cogitar, porém, das medidas de prevenção ou de acertamento amigável da Lei n. 84-148, de $1^{\circ}$ de março de 1984 da França.

Para Requião (1995b, p. 3) tem um conceito bastante simples no tocante a concordata:

O instituto da concordata visa resolver a situação econômica de insolvência do devedor, ou prevenindo e evitando a falência (concordata preventiva) ou suspendendo a falência (concordata suspensiva), para proporcionar a recuperaçáo e restauração da empresa comercial.

Almeida (2006, p. 302) ressalta os conceitos de recuperação de empresas, tal como concordata, uma vez tamanha similaridade dos objetivos: "[...] recuperar, economicamente, o devedor assegurando-lhe, outrossim, os meios indispensáveis à manutenção da empresa, considerando a função social desta”.

A nova lei de Falência, porém, tem tal objetivo previsto no artigo 47:

A recuperação judicial tem por objetivo viabilizar a superação da situação da crise econômico-financeira do devedor, a fim de permitir a manutenção da fonte produtora, do emprego dos trabalhadores e dos interesses dos credores, promovendo, assim, a preservação da empresa, sua função social e o estímulo à atividade econômica (Brasil, 2008, p. 80). 
A Recuperação de Empresas, portanto, tem seu conceito vinculado à preservação da atividade econômica, em que pese uma verdadeira conjugação de interesses diversos, como confirma Almeida (2006, p. 302):

O conceito póe em relevo a preocupação de preservar a empresa, vista esta como verdadeira instituição social para a qual se conjugam interesses diversos: o lucro do titular da empresa (empresário ou sociedade empresária); os salários (de manifesta natureza alimentar) dos trabalhadores; os créditos dos fornecedores; os tributos do Poder Público.

No caso da recuperação em sua forma extrajudicial, define Almeida (2006, p. 353) em parte da sua obra:

Em que consiste a recuperação extrajudicial de empresa?

R: Como o próprio nome deixa entrever, a recuperaçáo extrajudicial é verdadeira moratória, ou seja, acordo celebrado pessoalmente (sem intervenção judicial) do devedor com seus credores, estabelecendo novaçáo e outras formas de pagamento, tal como dilação de prazos, etc.

O Direito cria mecanismos de recuperação e reestruturação da atividade econômica, sob fundamento de evitar que as crises provoquem efeitos danosos a uma economia local, regional ou, até mesmo, nacional, como no caso de inúmeras passagens históricas que foram posteriormente acompanhadas por séria regulamentação. Assim assevera Coelho (2006, p. 233):

A crise fatal de uma grande empresa significa o fim de postos de trabalho, desabastecimento de produtos ou serviços, diminuição na arrecadação de impostos e, dependendo das circunstâncias, paralisaçáo de atividades satélites e problemas sérios para economia local, regional ou até mesmo nacional. Por isso, muitas vezes o direito se ocupa em criar mecanismos jurídicos e judiciais de recuperação da empresa.

Como exemplo, na História dos Estados Unidos, um dos primeiros diplomas que disciplinou a recuperação de empresas surgiu em 1934, visando a atenuar uma importante crise histórica que foi a "Quebra da Bolsa de Nova York". Coelho (2006, p. 233) faz seu comentário: 
Nos Estados Unidos, o primeiro diploma de direito estatutário dispondo sobre a recuperação judicial de empresas surgiu em 1934, visando atenuar os efeitos da crise provocada pela quebra da Bolsa de Valores de Nova York em 1929.

No Brasil, em 1993, o Poder Executivo envia ao Congresso o projeto responsável pelo nosso mecanismo de reestruturação da empresa, inclusive na modalidade extrajudicial, visando à prioridade que o legislador deve-se ter na função social e no interesse público, acompanhando a nova sistemática de 1988 com a vigente Constituição da República, como ressalta Taddei (2005, p. 148):

Diante da Necessidade de Reforma, por iniciativa do Poder Executivo, foi apresentado o Projeto de Lei n. 4376/1993, que após 11 anos de tramitação recheada de emendas e substitutivos, pressão das entidades representativas do comércio, indústria, instituiçóes financeiras, do Word Bank e de outros setores interessados, foi aprovado, correspondendo à Lei n. 11.101/2005.

Em 1993 o projeto apresentado por iniciativa do Poder Executivo era bastante tímido. Após longa data até sua aprovação (em 2004), houve alteração significativa no texto, que deu origem a um projeto bastante diferente desde a apresentação. Assim destaca Coelho (2006, p. 240):

Em 1993, o Poder Executivo enviou ao congresso um projeto de reforma da Lei de Falências que vigia desde 1945 . O projeto era bastante tímido em termos de alteraçôes. Em 2004, o Poder Legislativo aprovou, depois de longa tramitação, um projeto bem diferente, com alterações mais significativas. Ele foi sancionado como Lei n. 11.101/2005 (LF). Além de atualizar a lei falimentar, a reforma teve o objetivo de contribuir em duas frentes importantes para a economia brasileira do início do século XXI: a luta contra o desemprego e a retomada do desenvolvimento econômico. Na primeira, procurou-se desacelerar a elevação do nível de desemprego por meio da introdução do instituto da recuperaçáo judicial. Na medida em que empresas viáveis possam se reorganizar, mantêm-se os postos de trabalho a ela correspondentes. Na segunda frente, medida como a venda dos bens do devedor independentemente da verificação dos créditos e a investigação de crime falimentar ou alterações na classificação dos credores foram introduzidas com o objetivo de reduzir o risco associado à insolvência do devedor e, conseqüentemente, os spreads e juros bancários. 
Ainda no período do trâmite do Projeto de Lei n. 4.776/93, doutrina Pacheco (2001, p. 7) (em edição de 2001, antes de ser aprovado como lei pelo Congresso) no tocante à matéria e seu histórico:

O Projeto de Lei n. 4376/93, originário do Poder Executivo e por este enviado ao Congresso pela Mensagem n. 1014, de 21.12.1993, foi elaborado pela comissão constituída pela Portaria n. 233/MJ, tendo por objeto regular a falência, a concordata preventiva e a recuperação de empresas que exercem atividade econômica regida pelas leis comerciais. Foi ele distribuído a três comissóes técnicas, com poder terminativo: Comissão do Trabalho, Administração e Serviço Público; Comissão de Economia, Indústria e Comércio, e Comissão de Constituição e Justiça e de Redação.

Pacheco (2001, p. 7) ressalta o trabalho das Comissóes em seu trâmite até a aprovação final:

Na primeira Comissão, desde 24.01.1994, foi distribuído ao relator Dep. Nelson Marquezelli, tendo sido, no prazo regimental, apresentadas, nessa Comissão, 26 emendas: 23 pelo Dep. Amaral Neto, 02 pelo Dep. Augusto de Carvalho e 01 pelo Dep. Beraldo Boaventura. A emenda n. 024/94 propunha um substitutivo, sob o argumento de que o projeto preocupava-se táo somente com devedor falido, sem se considerar o emprego, a produção e poupanças sociais. Posteriormente, foi designado um relator o Dep. Osvaldo Biolchi, que apresentou um substitutivo ao PL n. 4376/93, que na versão de 18.04.1996, tinha 171 artigos, distribuídos em seis títulos, respectivamente dedicados às Disposiçôes Preliminares (Tít. I), às Disposições Comuns à Recuperação e à Liquidação Judicial (Tít. II), à Recuperação de Empresa (Tít. III), à Liquidação Judicial do Devedor (Tít. IV), aos crimes (Tít. V), às disposições finais (Tít. VI).

A Comissão Especial adotou a subemenda de 18.3.1998 com objetivo de regular a recuperação e liquidação judicial de devedores, pessoas jurídicas e pessoas físicas, que exerçam atividade econômicas, revogando, assim, o Decreto-Lei $\mathrm{n}$. 7.661/1945, instituindo a recuperaçáo judicial, tal como se nota a seguir, segundo Pacheco (2001, p. 8):

Em 18.03.1998, adveio subemenda à Emenda Global oferecida ao substitutivo, adotado pela Comissão Especial. 
Essa subemenda tem em vista "a recuperação e liquidação judicial de devedores, pessoas jurídicas e pessoas físicas, que exerçam atividades econômicas”.

[...] a subemenda tem em mira revogar o Decreto-Lei n. 7.661/45 e instituir a recuperação judicial. Ao fazê-lo, vinculou-se, claramente, ao sistema francês [...].

No relatório do PLC n. 71/2003, o senador Ramez Tebet destaca os princípios que deveriam nortear a lei a ser aprovada, dentre os quais a Funçáo Social da Empresa. Tais princípios repercutiram no texto final do projeto aprovado no Senado Federal em seis de junho de 2004, remetido à Câmara dos Deputados em razão das alteraçóes, quando foi aprovado, finalmente, em 14 dezembros de 2004, resultando na Lei n. 11.101/2005, de 9 de fevereiro de 2005, com vacatio Legis de 120 dias (TADDEI, 2005, p. 148).

Todo o tratamento histórico do instituto na legislação possui relevâncias primordiais que merecem destaque: oportunidade de reestruturação do empresário pressupóe valores que, historicamente, não condizem com sua origem, razão de o próprio nome "falência" significar condutas maliciosas e fraudulentas; fraudes decorrentes de um modelo menos formal de reestruturaçáo do falido pressupóe analisar a inversão de valores, uma vez que o falido, visto de forma negativa, náo teria a concessão legal de uma possível reestruturação da atividade que exerce, ainda que tenha sido vítima de fatores imprevisíveis que caracterizam a economia de mercado; a instabilidade do instituto no ordenamento brasileiro para verificaçáo dos motivos que levaram o legislador a ora positivá-lo, ora revogá-lo; os valores que fizeram a recente previsão legislativa e os princípios norteadores da Nova Lei de Falência que foram destacados pelo relatório do senador Ramez Tebet (rel. do PLC 71/2003), dentre os quais Preservação da Empresa, Funçáo Social da Empresa, Proteção ao Trabalhador, e outros condizentes com a vigente Constituição de 1988 e que, em que pese o tempo até sua aprovaçáo pelo Congresso, superou dez anos de longo debate.

Define-se como modelo formal de recuperaçáo de empresas, com base na recente lei que ganhou vigência a partir de 2005 (Lei n. 11.101/2005), a recuperação de empresas em sua modalidade judicial, uma vez que, em comparaçáo com a modalidade menos formal - Recuperação Extrajudicial - decorrem certas faltas, solenidades, órgãos fiscalizadores, dentre outras diferenças. 
Para tal comparação de um modelo em detrimento ao outro, faz-se necessário a abordagem desta modalidade formal de recuperação que, segundo algumas doutrinas, tem seu processamento dividido em três fases. Coelho (2006, p. 402) aponta essas fases:

O processo de recuperaçáo judicial se divide em três fases bem distintas. $\mathrm{Na}$ primeira, que se pode chamar de fase postulatória, a sociedade empresária em crise apresenta seu requerimento do benefício. Ela começa com a petição inicial de recuperação judicial e se encerra com o despacho judicial mandando processar o pedido (3.1.). Na segunda fase, a que se pode referir como deliberativa, após a verificaçáo do crédito (subitem 3.2.), discute-se e aprova-se um plano de reorganização (subitem 3.3.). Tem início com o despacho que manda processar a recuperação judicial e se conclui com a decisão concessiva do benefício (subitem 3.4.). A derradeira etapa do processo, chamada de fase de execuçáo, compreende a fiscalização do cumprimento do plano aprovado. Começa com a decisáo concessiva da recuperaçáo judicial e termina com a sentença de encerramento do processo (3.5.).

\section{DAS RAZÕES DA LEGALIZAÇÃO DA FORMA EXTRAJUDICIAL DE RECUPERAÇÃO}

Com o advento da Constituição de 1988, houve prevalecimento de novo pensamento no tocante ao interesse público e ao interesse individual.

A nova sistemática caracterizou-se pela prioridade de um novo e inovador conjunto de princípios, dentre os quais a Função Social que, em conformidade com o novo conceito de Estado de Direito, na sua modalidade democrática social de Direito, voltava-se na prevalência das demandas públicas e sociais sobre os interesses individuais.

Sendo assim, verificam-se consequências desta nova ordem nas diversas áreas do Direito, tais como o próprio processo civil, no qual a tutela substitutiva foi posta como exceção, ou seja, ainda que aquele que violou o Direito tivesse condiçóes de arcar em pecúnia com as perdas e danos, ele tem de, em regra, satisfazer o direito na sua forma específica. Ainda no Direito Civil com o Código de 2002, marcado 
pelo fenômeno da "publicização", tendências crescentes das normas de ordem pública no interesse social e coletivo, mitigar a autonomia da vontade, sem falar no novo conjunto axiológico de valores previstos, tais como justiça contratual, boa-fé objetiva e função social do contrato.

Desse modo, não foi diferente no Direito de Empresas, em que muitos dos princípios resultantes desta nova ordem apareceram implicitamente na vigente carta.

Lembra-se que não perde a importância por se tratar de princípio não expresso, ou seja, implícito na Constituição, nas palavras do professor Campinho (2005) citado por Martins Junior (2005, p. 52):

O princípio da preservação da empresa, ainda que de forma indireta, encontra assento constitucional. Os valores sociais do trabalho e a livre iniciativa, princípios fundamentais da república (art. $1^{\circ}$, inc. IV), só se alcançam com um sólido e estimulado exercício da empresa, posto que seja fonte de trabalho, de produçáo de bens e serviços para o mercado e geração de tributos. A preservação da empresa é condição preponderante para que se realizem os princípios informadores da ordem econômica, notadamente a propriedade privada, a sua função social, a livre concorrência, a defesa do consumidor, a redução das desigualdades regionais e sociais e a busca do pleno emprego.

Um exemplo, no caso concreto, que demonstra o interesse público e social em preservar a empresa e o fundamento jurídico na previsão da Recuperação Judicial, pode ser verificado no seguinte caso descrito pela Revista (2008):

O juiz Marcos Aurélio dos Reis Ferreira, da Vara Especializada de Falência e Concordata de Cuiabá-MT, homologou hoje (13.06) o plano de recuperação judicial da empresa TUT Transportes. O plano aprovado pela assembléia geral de credores realizada no último dia 30 , que contou com a presença de mais de 300 pessoas, entre trabalhadores, fornecedores e demais detentores de crédito da empresa, permite que o passivo de $\mathrm{R} \$ 21$ milhóes da empresa seja pago integralmente através da venda de bens não operacionais (imóveis urbanos e rurais da empresa). Do total de passivo, $\mathrm{R} \$ 6$ milhōes referem-se a débitos com ações da Justiça Trabalhista e o restante em dívidas com fornecedores e autores de açôes contra a empresa. A empresa conseguiu ainda um deságio de $70 \%$ em débito com o Banco Itaú. Com a aprovação do plano foram mantidos mais de 
4 mil empregos, mil diretos e 3 mil indiretos. Ao todo a empresa de transporte tem receita de $\mathrm{R} \$ 3$ milhóes ao mês. $\mathrm{O}$ processo de recuperação judicial foi resolvido em pouco mais de 60 dias, o que permitirá à empresa, com as finanças recuperadas, comprar 14 novos ônibus rodoviários, quatro no próximo mês e 10 até o fim do ano.

A Função Social da empresa está vinculada à amplitude da concepção constitucional de propriedade, quando a Constituição Federal não somente garantiu o direito individual da propriedade como também condicionou tal direito individual à função social (art. 50, inc. XXII e XXIII da CF/88). Também tal preceito é condicionador do Direito individual da propriedade que transcendeu para muitos outros institutos, dentre os quais a atividade empresária, sob fundamento de ser a atual tendência constitucional, assim como alerta Comparato (1990, p. 76): "a tendência constitucional é pela função social dos institutos jurídicos, do que se precisa incluir a empresa como operadora de um mercado socialmente socializado".

Nesse contexto, destaca-se a maneira que, com a nova sistemática constitucional, deve-se aplicar tradicional preceito individualista, ou seja, em conformidade e harmonia com o interesse público.

Foi visando a esses interesses sociais que o novo diploma priorizou os valores sociais sobre os interesses particulares e creditícios, mantendo a atividade econômica do empresário, sob assento na sua fonte produtiva, o numerário de emprego, fomento no mercado e outros interesses sociais, ainda que com previsão de forma extrajudicial e maior riscos de fraudes.

Vale ressaltar que o regime falimentar anterior estava desvinculado a novas concepçóes de Preservação e Função Social da empresa, priorizando mais a satisfação dos credores e do particular.

Apesar de uma forte regulação e positivação estatal, decorrente do contexto de ditaduras e de suas políticas totalitárias vividas, a antiga lei ainda trazia concepçóes favoráveis ao credor, que tornam impraticáveis e de grande dificuldade a reestruturaçáo por meio da concordata, além do que a modalidade extrajudicial configurava "concordata branca" e era entendida como hipótese de falência. Conforme Souto Júnior (2008), 
Para que a recuperação da empresa seja possível é fundamental o estabelecimento de incentivos corretos, a partir de balanceamento adequado de direitos entre devedor e credores e de justa divisão do risco.

Um arcabouço legal que privilegia em demasia a falência e aborta tentativas de reestruturação de empresas viáveis, gera perda econômica em termos de renda e emprego em favor do ganho individual dos credores.

Um sistema legal de orientação excessivamente favorável aos credores tem impacto sobre as açôes dos devedores. Prejudicam a qualidade da seleção dos projetos financiados, além de piorarem a divisão do risco ao incentivar os devedores a transferir renda dos estados de falência (onde não recebem nada) para os estados pré-falimentares aceitando, por exemplo, taxas de juros mais elevadas ou se voltando para projetos de alto risco.

Ressalta-se que para proteger o crédito público não é necessário a eliminação da empresa em crise, mas sim de acordo com a eficiência, combinar os interesses creditícios com o interesse sociais e públicos na manutenção da empresa viável, como sugere Souto Júnior (2008):

Proteger o crédito público não implica, necessariamente, na eliminação da empresa em crise. Por outro lado, de nada adiante garantir a sobrevivência de empresas inviáveis. Combinar, de forma eficiente, as infinitas possibilidades que se intercalam entre estas duas verdades, é, justamente o papel maior a ser desempenhado pelas alternativas contidas nas regras na nova Lei de Falências e de Recuperação de Empresas.

\section{CONSIDERAÇÕES FINAIS}

A relevância histórica e institucional do modelo extrajudicial de recuperação justifica-se na necessidade de verificação das razóes que levaram o legislador pátrio a oscilar no decorrer das várias leis que vigoraram no ordenamento jurídico brasileiro. 
Nota-se que esses argumentos que proibiram a figura extrajudicial de recuperaçáo no ordenamento jurídico da época (contexto da revogada legislação falimentar), e que entenderam o instituto como concordata branca, sendo hipótese de falência, são motivos que não deixaram de existir no novo e atual contexto com o advento da Lei n. 11.101/2005 (Nova Lei de Falências).

Desse modo, conclui-se que ainda existe potencial de fraudes que sonda a figura institucional da forma extrajudicial, de modo que não se pode afirmar que foi este o fator primordial para osculaçôes na proteção jurídica marcada pela apresentada instabilidade da proteção no respectivo histórico verificável no ordenamento jurídico brasileiro.

O retorno e a atuação do legislador (Lei n.11.101/2005) em novamente positivar e prever a figura no ordenamento pátrio, tem como justificativa não a redução de índices de fraudes ou ausência de riscos de conluios para o instituto, mas sua adequação na nova sistemática constitucional com o advento da Constituição Federal de 1988.

De acordo com a nova ordem constitucional, houve o prevalecimento dos interesses sociais sobre os interesses particulares e creditícios, mantendo a atividade econômica do empresário e visando à fonte produtiva, o numerário de emprego e outros interesses sociais.

Vale ressaltar que o regime falimentar anterior estava desvinculado a novas concepçóes de Preservação e Função Social da empresa. Priorizava-se a satisfação dos credores e do particular, apesar da forte regulação e positivaçáo estatal, decorrente do contexto de ditaduras e políticas totalitárias vividas no período em que a revogada lei entrou em vigência.

A revogada lei, desse modo, era marcada de excessivo individualismo e de concepçôes favoráveis ao credor, que tornavam impraticáveis e de grande dificuldade a reestruturação mediante a concordata.

Considerava-se a modalidade extrajudicial como "concordata branca", entendida como hipótese de falência, de forma que os riscos que os credores não queriam correr na satisfação de seus créditos fossem valorados com superioridade 
ante os empregos e o fomento no mercado, dentre outras consequências que os princípios da função social e a preservação da empresa vieram evitar com o advento da Constituição Federal de 1988.

\section{REFERÊNCIAS}

ALMEIDA, Amador Paes. Curso de falência e recuperação de empresa. 22. ed. São Paulo, Saraiva, 2006.

. Curso de falência e concordata. 15. ed. São Paulo: Saraiva, 1997.

ANDRADE, Jorge Pereira. Manual de falência e concordatas. 3. ed. São Paulo: Atlas, 1992.

BRASIL. Decreto-Lei n. 7.661, de 21 de Junho de 1945. Lei de Falências. Disponível em: <http://www.planalto.gov.br/ccivil_03/Decreto-Lei/Del7661.htm>. Acesso em: 10 ago. 2008.

CAHALI, Yussef Said. Fraudes contra credores. 1. ed. São Paulo: Revistas dos Tribunais, 1990.

CAMPINHO, Sérgio. O direito de empresa à luz do novo código civil. 2. ed. Rio de Janeiro: Renovar, 2003.

COELHO, Fabio Ulhoa. Comentários à nova lei de falência e de recuperação de empresas. São Paulo: Saraiva, 2005.

. Curso de direito comercial. 3. ed. São Paulo: Saraiva, 2002. V. 3.

. Curso de direito comercial. 6. ed. São Paulo: Saraiva, 2006. V. 3.

COMPARATO, Fábio Konder. Direito empresarial: estudos e pereceres. São Paulo: Saraiva, 1990.

DELMANTO JUNIOR, Sérgio. Código penal comentado. 4. ed. Rio de Janeiro: Renovar, 1998.

DINIZ, Maria Helena. Direito civil brasileiro. 20. ed. São Paulo: Saraiva, 2006. V. 4.

LACERDA, José Cândido Sampaio. Manual do direito falimentar. 14. ed. Rio de Janeiro; São Paulo: Biblioteca Jurídica Freitas de Bastos, 1999.

MARTINS JÚNIOR, Silvio Osmar. O novo regime falimentar brasileiro: o princípio da preservação da empresa e a recuperação extrajudicial. Marília: Editora Univem, 2005. 84p.

MIRABETE, Julio Fabrini. Manual de direito penal. 22. ed. São Paulo: Atlas, 2004. V. 2.

MIRANDA, Pontes de. Tratado de direito privado. 1. ed. Rio de Janeiro: Editor Borsoi, 1960. 
MONTEIRO, Washington de Barros. Curso de direito civil. 37. ed. São Paulo: Saraiva, 2003a. V. 3.

. Curso de direito civil: parte geral. São Paulo: Saraiva, 2003 b.

NORONHA, E. Magalhães. Direito Penal. 25. ed. São Paulo: Saraiva, 1991. V. 2.

PACHECO, José Silva. Processo de falência e concordata. 12. ed. Rio de Janeiro: Forense, 2001.

REQUIÃO, Rubens. Curso de direito falimentar. 16. ed. São Paulo: Saraiva, 1995a. V. 1.

Curso de direito falimentar. 14. ed. São Paulo: Saraiva, 1995b.

REVISTA RDM. Empresa consegue recuperação judicial e mantém mais de 4 mil empregos. Disponível em: <http://www.ersadvocacia.com.br/conteudo.php?sid=58\&cid=662>. Acesso em: 210 ago. 2008.

SOUTO JÚNIOR, Carlos. Nova lei de recuperação de empresas (Lei no 11.101/2005). Alguns aspectos. Jus Navigandi, Teresina, ano 10, n. 1.096, 2 jul. 2006. Disponível em: <http://jus2.uol.com.br/doutrina/texto.asp?id=8587>. Acesso em: 20 ago. 2008.

TADDEI, Marcelo Gazzi. Manual de direito comercial. São Paulo: Saraiva, 2005.

Recebido em: 19/10/2015

Aceito em: 22/12/2015 